\title{
Assessment of the heterogeneity and petrophysical evaluation of reservoirs in the "Akbar Field", Niger Delta, Nigeria
}

\author{
O. A. Anyiam ${ }^{1}$ - P. J. Andrew ${ }^{1}$ I. C. Okwara ${ }^{1}$
}

Received: 29 October 2016/ Accepted: 29 May 2017/Published online: 9 June 2017

(c) The Author(s) 2017. This article is an open access publication

\begin{abstract}
This study involved the use of well logs from four wells (JAP-1-4) to evaluate the reservoirs' quality and to determine the clay distribution trends of the reservoirs using the neutron-density crossplot in the "Akbar Field" Coastal Swamp depobelt, Niger Delta. The results of the analysis show that a total of fifteen (15) reservoirs (A1A15) were delineated and they are relatively laterally continuous. There is an increase in reservoir thickness as the delta prograded, giving rise to good sand development down-dip at the shallow and intermediate intervals. From the interpreted gamma ray log motifs, it was observed that reservoirs A1-A5, A8, A10 and A12-A14 are tidal channels; A7 and A11 are fluvial channels; A9 and A15 are shoreface sands, while only A6 is of coastal plain deposit. The reservoir porosities show good-excellent values that range from 0.15 to $0.38 \mathrm{v} / \mathrm{v}$ (15-38\%) except in JAP-1 well where reservoirs A4, A5 and A9-A11 have poor to fair value of $0.11 \mathrm{v} / \mathrm{v}(11 \%)$. Also, the permeability values are good to excellent (1866.24-75873.41 md), except for the few sands in JAP-1 well that are low (3.42-72.82). Additionally, the neutron-density crossplots show that the reservoirs contain mainly laminated and structural clays with few dispersed clays. Despite the presence of these three clay types, the reservoir qualities of the reservoirs are not relatively affected. Although the horizontal fluid flow may not have been affected, the vertical flow could be
\end{abstract}

O. A. Anyiam

okwudiri.anyiam@unn.edu.ng

1 Department of Geology, University of Nigeria, Nsukka, Nigeria impaired due to the presence of numerous laminated clay/ shale baffles compartmentalizing the reservoirs.

Keywords Reservoir quality - Clay volume/distribution . Depositional environment

\section{Introduction}

Sandstone reservoirs are rarely lithologically homogeneous because they are deposited with shale or clay matrices which are often of varying morphology and mineralogy. The inclusion of shale particles and clay minerals within the sandstone matrix tends to reduce the quality of the formation as reservoir and makes the petrophysical interpretation of such reservoir difficult (Asquith and Krygowski 2004). Clay minerals require special attention because of their specific effects on the reservoirs and log data. They tend to reduce porosity and permeability and can act as barriers to the lateral and vertical flow of fluids. The clay bound water, however, produces a response similar to porosity on many individual logs.

Accurate prediction of clay volume and form distribution in the reservoirs will enable a better understanding of how clays affect the reservoir properties. It also helps to obtain reliable estimation of the volume of producible hydrocarbons in the pore spaces, consequently reducing uncertainties in formation evaluation of heterogeneous sandstone reservoirs (Mode et al. 2013). The objective of this study is to use well logs to evaluate the reservoir quality and to determine the clay distribution trends of the reservoirs in the "Akbar Field" Coastal Swamp depobelt, Niger Delta, Nigeria (Fig. 1). 


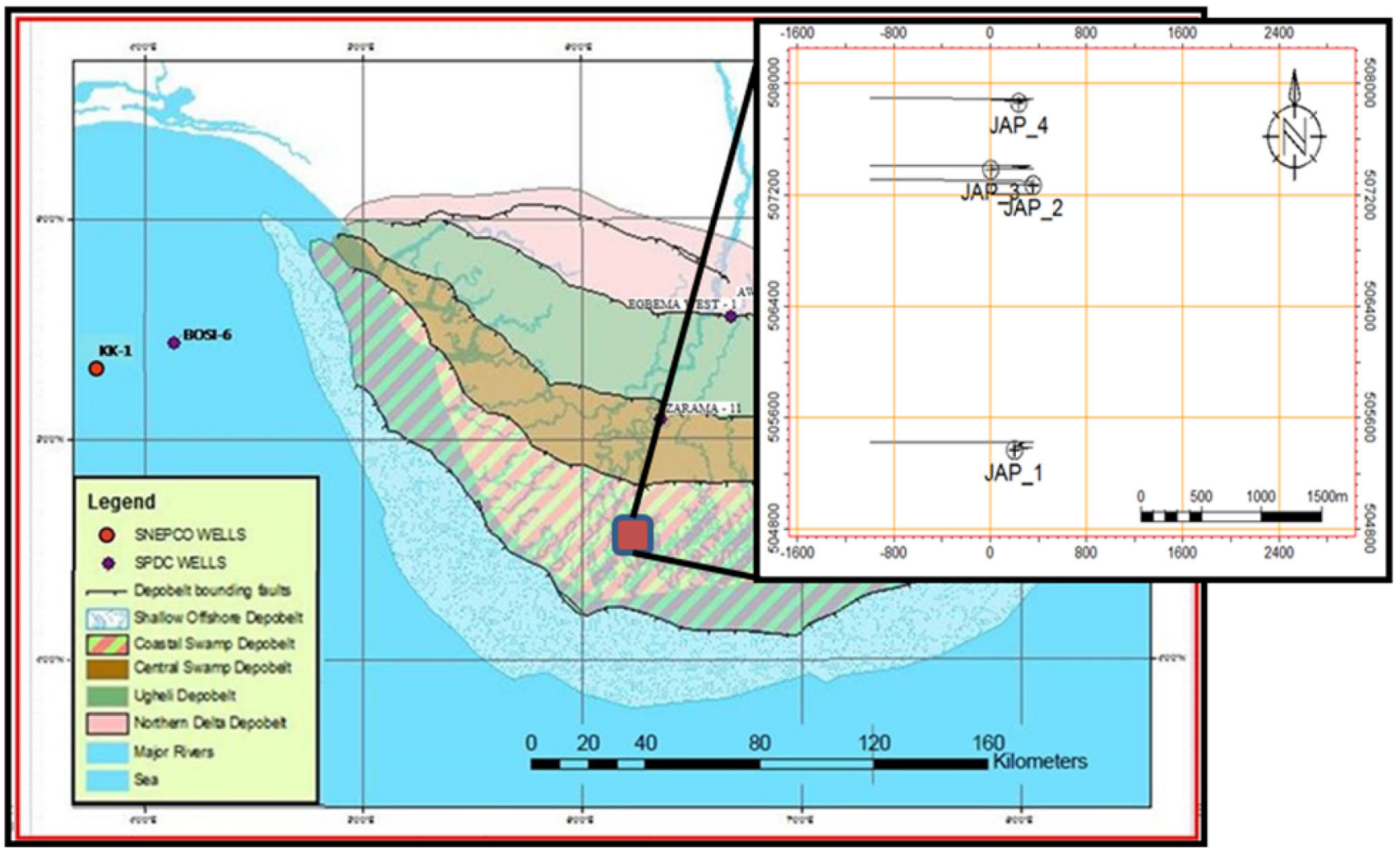

Fig. 1 Map of the Niger Delta depobelts, showing the location of “Akbar Field” (Modified from Okosun and Osterloff 2014)

\section{Regional stratigraphic setting}

The Niger Delta forms the seaward end of a NE-SWoriented failed rift basin called the Benue Trough and is bounded to the east by the Cameroon volcanic line, to the west by the Dahomey Basin and to the south (seaward) by the 4000-m bathymetry contour (Corredor et al. 2005). The trough was formed during the opening of South Atlantic following the separation of Equatorial Africa from South America in the Early Cretaceous times (Whiteman 1982; Mascle et al. 1986; Fairhead and Binks 1991). From the early stages of the trough development, it was progressively filled with younger post-rift deposits; by Late Eocene times, a delta had begun to build across the continental margin (Burke 1972; Damuth 1994). The delta currently has an area of about $140,000 \mathrm{~km}^{2}$ both in subaerial exposure and associated deepwater fans and is up to $12 \mathrm{~km}$ in vertical thickness (Damuth 1994). The structural zones according to Corredor et al. (2005) comprised of the extensional province on the shelf, the mud diapirs province, the detachment fold province, the inner fold and thrust belt, the translational province and the outer fold and thrust belt in the deepwater end. The delta is stratigraphically divided into three diachronous sequences of Eocene to Recent age named the Akata, Agbada and Benin formations (Fig. 2); (Short and Stauble
1965; Avbovbo 1978; Evamy et al. 1978; Whiteman 1982; Knox and Omatsola 1989; Doust and Omatsola 1990). In deepwater Niger Delta, the Benin Formation is absent-with only the Agbada and Akata formations present. The Benin Formation is the shallowest unit of the Niger Delta clastic wedge and occurs throughout the entire onshore and part of the offshore Niger Delta. The overall thickness of the formation varies from $1,000 \mathrm{ft}$ in the offshore to $10,000 \mathrm{ft}$. The sands of the formation are in the form of point bars, channel fills and natural levees. The oldest known age of the Benin Formation at the surface is Miocene while at the subsurface is Oligocene. The Agbada Formation underlies the Benin Formation and occurs throughout Niger Delta clastics with thicknesses ranging from 3000 to $4500 \mathrm{~m}$, where it outcrops around Ogwashi and Asaba, southern Nigeria (Doust and Omatsola 1990). The lithologies consist of alternating sands, silts and shales, stacked within ten- to hundred-feet successions and defined by progressive upward changes in grain size and bed thickness. The sediments are interpreted to be fluvial-deltaic, and the age ranges from Eocene to Pleistocene. Most structural traps observed in the Niger Delta are developed during the syn-sedimentary deformation of the Agbada paralic sequence (Evamy et al. 1978). The interbedded shales within the formation form the primary seal. 

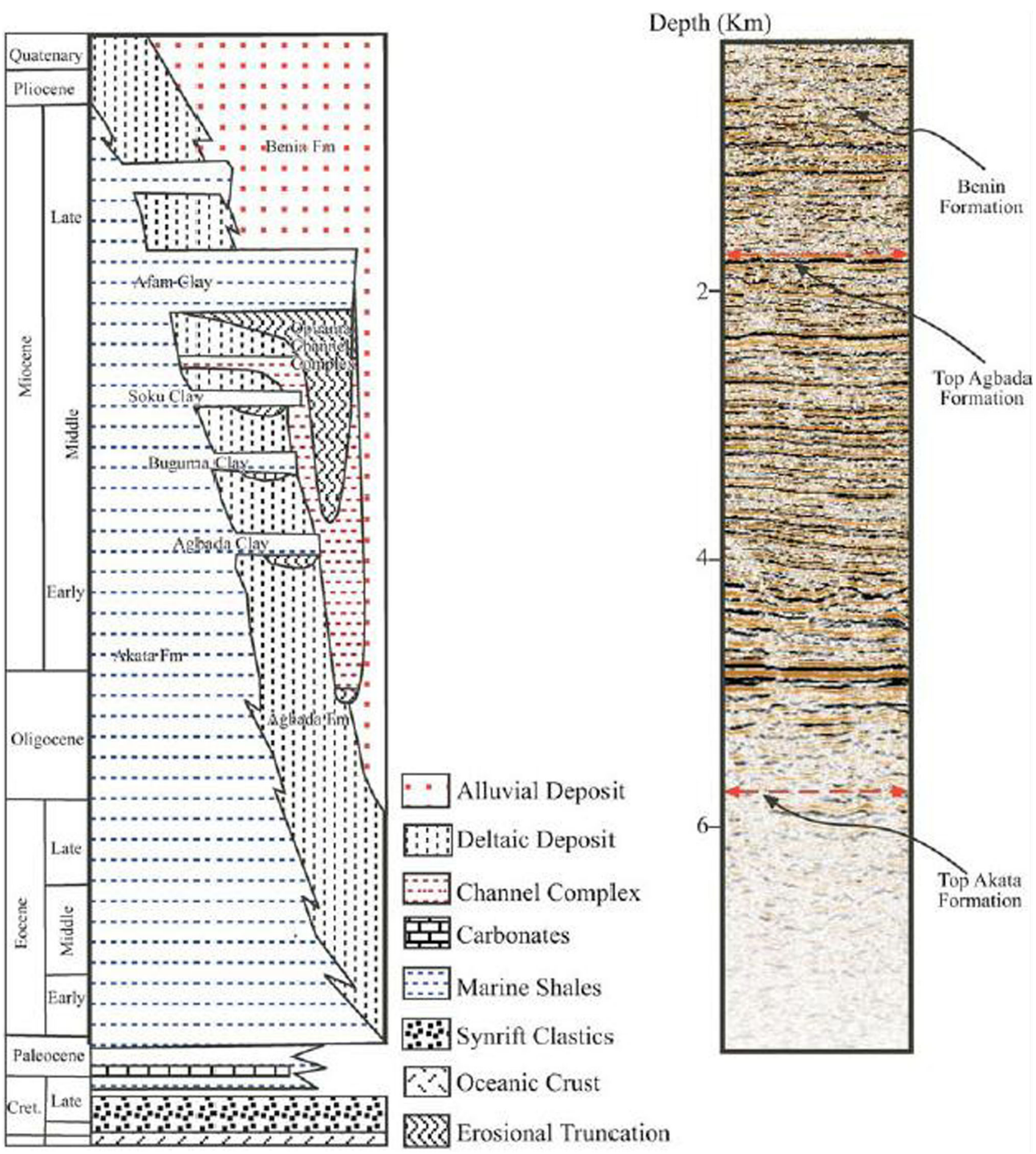

Fig. 2 Niger Delta regional stratigraphy and variable density seismic display of the main stratigraphic units with corresponding reflections (Lawrence et al. 2002)

The Akata Formation is the basal sedimentary unit estimated to be $21,000 \mathrm{ft}$ thick in the central part of the clastic wedge (Doust and Omatsola 1990). It is characterized by dark gray shales and silts, with occasional sands of probable turbidite flow origin (Doust and Omatsola 1990). The Akata shales are typically under-compacted and overpressured. The shales also form diapiric structures including shale swells and ridges which often intrude into overlying Agbada Formation. 


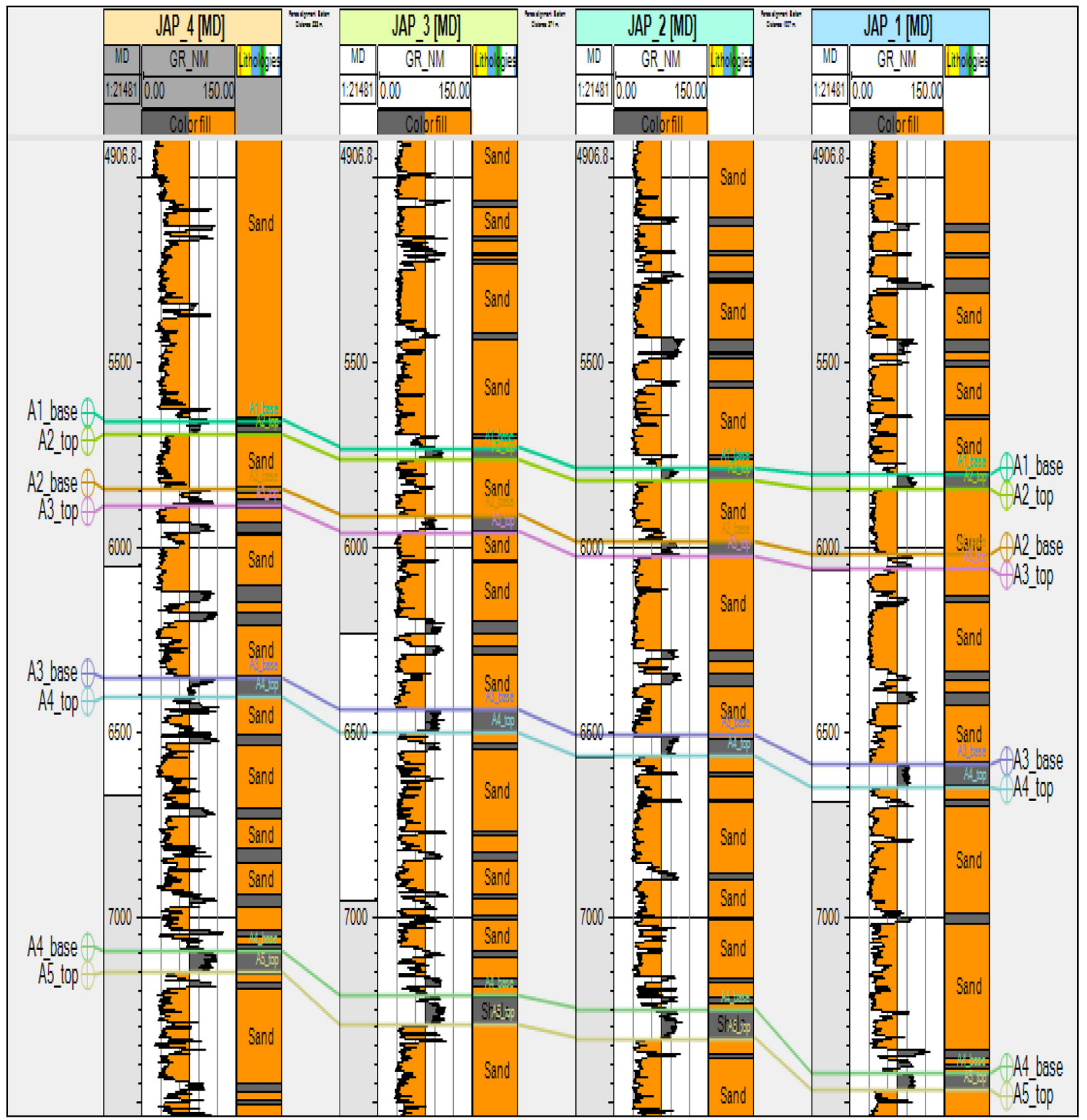

Fig. 3 Correlation panel of reservoirs A1-A4 in the wells across field

\section{Materials and methods}

This study involves the formation evaluation of four exploration wells (JAP-1-4 wells) located in the "Akbar Field," Coastal swamp depobelt, Niger Delta. The suite of well logs comprised gamma ray log (GR), compensated bulk density log, sonic log, deep laterolog (LLD) and shallow laterolog (LLS), and they were analyzed using Petrel and Interactive petrophysics softwares. The delineation of lithologies and reservoir thickness were carried out using single plot of GR log on Petrel software. Also, the reservoir quality parameters (e.g., clay volume, porosity, permeability, water saturation, etc.) of the delineated sands were evaluated using the Interactive Petrophysics software, which made use of the following equations to estimate the reservoir quality parameters as shown below. The volume of shale $\left(V_{\mathrm{sh}}\right)$ was calculated using the Larionov (1969) equation for Tertiary deposits. 


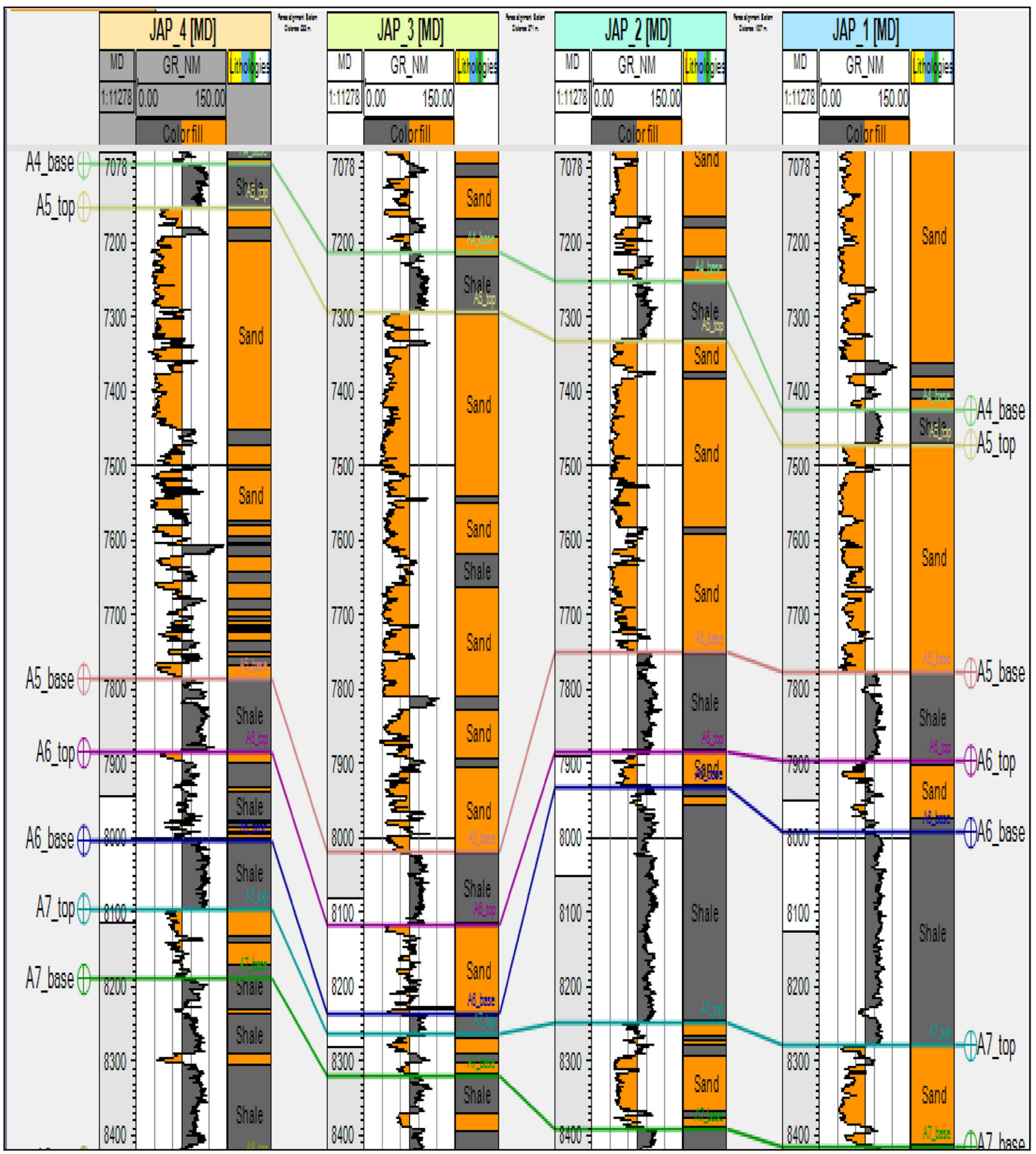

Fig. 4 Correlation panel of reservoirs A5-A7 in the wells across field

$V_{\mathrm{sh}}=0.083\left[2^{(3.7 \times 1 \mathrm{GR})}-1.0\right]($ Tertiary unconsolidated sand $)$.

(1)

Effective porosity $\left(\phi_{\mathrm{e}}\right)$ was estimated using the relation as;
$\phi_{\mathrm{e}}=\frac{p_{\mathrm{ma}}-p_{\mathrm{b}}}{p_{\mathrm{ma}}-p_{\mathrm{f}}}-V_{\mathrm{sh}}\left\{\frac{p_{\mathrm{ma}}-p_{\mathrm{sh}}}{p_{\mathrm{ma}}-p_{\mathrm{f}}}\right\}$

where $p_{\mathrm{ma}}=$ matrix density (usually $2.65 \mathrm{~g} / \mathrm{cc}$ sandstone), $p_{\mathrm{f}}=$ formation fluid's density $(1.0 \mathrm{gm} / \mathrm{cc}$ for water and 


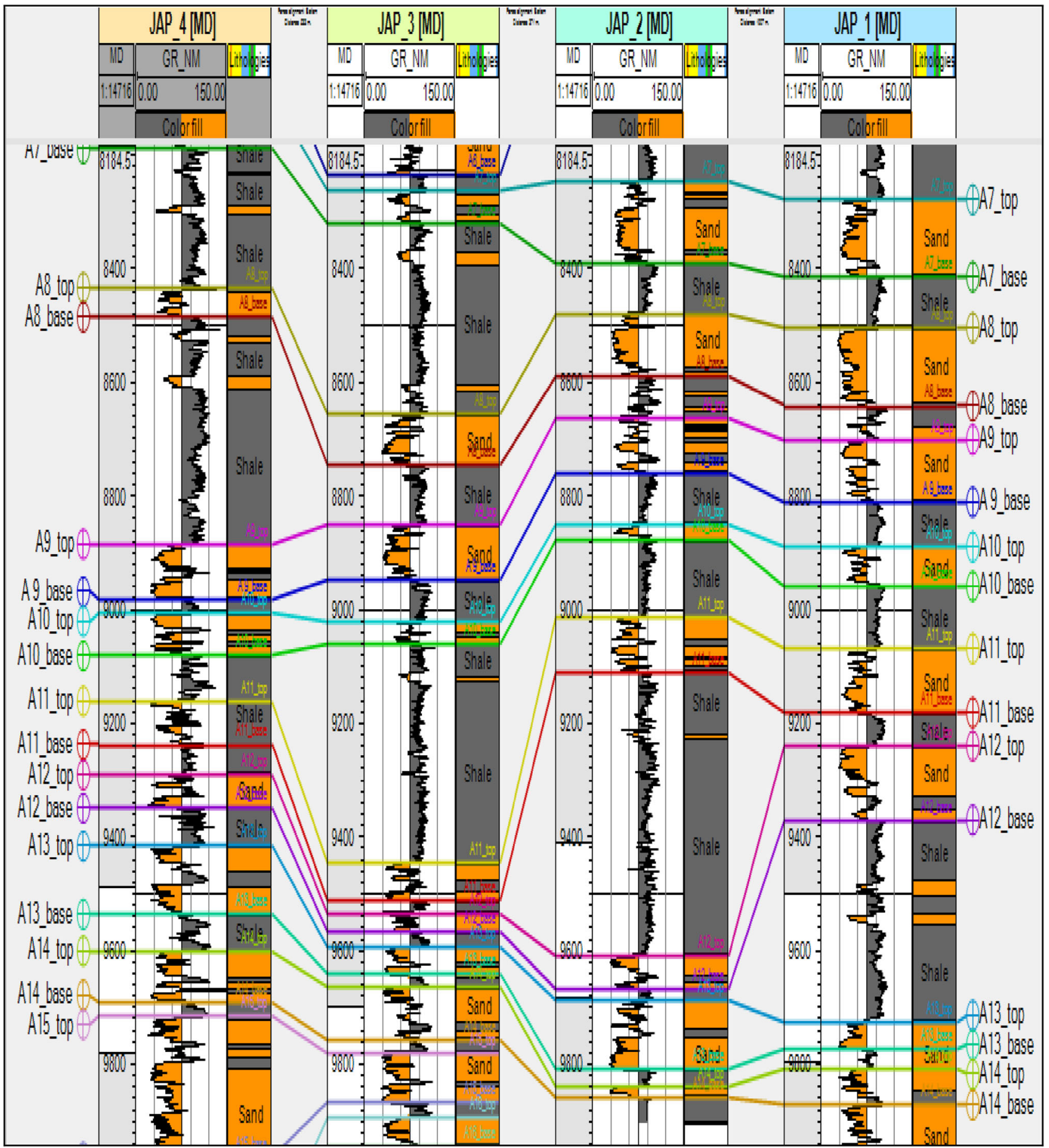

Fig. 5 Correlation panel of reservoirs A8-A15 in the wells across field

$0.8 \mathrm{~g} / \mathrm{cc}$ for hydrocarbon), $p_{\mathrm{b}}=$ formation bulk density (obtain from density $\log$ at $0.5 \mathrm{ft}$. interval), $p_{\mathrm{sh}}=$ density of the clay point interval. The water saturation was determined for the invaded zone using the Archie's equation given below:
$S_{\mathrm{W}}=\frac{a \times R_{\mathrm{W}}}{\phi^{m}}$

where $S_{\mathrm{w}}=$ water saturation of the uninvaded zone, $R_{\mathrm{t}}=$ true formation resistivity (from laterolog, LLD), $\phi$ 
Table 1 Environments of deposition of the reservoirs in all the wells using log motifs

\begin{tabular}{|c|c|c|c|c|c|}
\hline Sand & JAP-1 well & JAP-2 well & JAP-3 well & JAP-4 well & $\begin{array}{l}\text { Depositional } \\
\text { environment }\end{array}$ \\
\hline A1 & $\begin{array}{l}\text { Serrated to blocky } \\
\text { funnel shape }\end{array}$ & Blocky & Blocky & Blocky serrated & Channel \\
\hline A2 & $\begin{array}{l}\text { Serrated blocky bell } \\
\text { shape }\end{array}$ & Cylindrical and serrated & Serrated blocky bell shape & Blocky serrated bell shape & Channel \\
\hline A3 & $\begin{array}{l}\text { Serrated blocky bell } \\
\text { shape }\end{array}$ & Serrated blocky shape & Serrated blocky shape & Serrated blocky bell shape & Channel \\
\hline A4 & Serrated blocky shape & Serrated blocky shape & Serrated blocky shape & Serrated blocky bell shape & Channel \\
\hline A5 & Blocky to funnel shape & $\begin{array}{l}\text { Serrated blocky to funnel } \\
\text { shape }\end{array}$ & $\begin{array}{l}\text { Serrated cylindrical and } \\
\text { blocky shape }\end{array}$ & $\begin{array}{l}\text { Blocky and alternating funnel } \\
\text { and bell shape }\end{array}$ & Channel \\
\hline A6 & Irregular trend & Irregular trend & Irregular trend & Irregular trend & Basin plain \\
\hline A7 & Blocky to bell shaped & $\begin{array}{l}\text { Serrated cylindrical and } \\
\text { blocky shape }\end{array}$ & Blocky shape & Funnel shape & Fluvial channel \\
\hline A8 & Blocky to funnel shape & Blocky shape & Blocky shape & Blocky shape & Channel \\
\hline A9 & Blocky funnel shape & Blocky funnel shape & Blocky to bell shape & Blocky shape & Fluvial channel \\
\hline A10 & Funnel shape & Blocky shape & Blocky shape & Blocky shape & Channel \\
\hline A11 & Bell shape & Bell shape & Blocky bell shape & Bell shape & Fluvial channel \\
\hline A12 & Blocky shape & Blocky shape & Blocky shape & Blocky to bell shape & Channel \\
\hline A13 & Blocky to bell shape & Blocky to bell shape & Blocky to funnel shape & Blocky to funnel shape & Channel \\
\hline A14 & Blocky serrated shape & Blocky shape & Serrated blocky shape & Serrated blocky shape & Channel \\
\hline A15 & Blocky to funnel shape & - & Blocky shape & Serrated blocky funnel shape & Shoreface \\
\hline
\end{tabular}

Table 2 Average petrophysical parameters for the reservoirs in JAP-1 well

\begin{tabular}{|c|c|c|c|c|c|c|c|c|c|c|c|c|c|}
\hline $\begin{array}{l}\text { Reservoir } \\
\text { units }\end{array}$ & Top (ft) & $\begin{array}{l}\text { Base } \\
\text { (ft) }\end{array}$ & $\begin{array}{l}\text { Gross } \\
\text { thickness } \\
(\mathrm{ft})\end{array}$ & $\begin{array}{l}\text { Net } \\
\text { thickness } \\
(\mathrm{ft})\end{array}$ & $\mathrm{N} / \mathrm{G}$ & $\begin{array}{l}\mathrm{Av} V_{\mathrm{cl}} \\
(\mathrm{v} / \mathrm{v})\end{array}$ & $\begin{array}{l}\text { Av Phi E } \\
\text { (v/v) }\end{array}$ & $\begin{array}{l}\text { Av K } \\
\text { (md) }\end{array}$ & $\begin{array}{l}\text { Av } \\
\text { MHI }\end{array}$ & $\begin{array}{l}\text { Av } S_{\mathrm{w}} \\
(\mathrm{v} / \mathrm{v})\end{array}$ & $\begin{array}{l}\mathrm{Av} \\
S_{\mathrm{h}(\mathrm{v} / \mathrm{v})}\end{array}$ & $\begin{array}{l}\text { Av } \\
\text { Resistivity } \\
(\Omega \mathrm{m})\end{array}$ & $\begin{array}{l}\text { Fluid } \\
\text { type }\end{array}$ \\
\hline A1 & 164.95 & 5779.66 & 5614.71 & 5501.50 & 0.98 & 0.00 & 0.15 & 42.12 & 0.57 & 0.29 & 0.71 & 23.30 & Oil \\
\hline A2 & 5857.18 & 6028.00 & 170.82 & 170.82 & 1.00 & 0.00 & 0.15 & 42.12 & 0.62 & 0.47 & 0.53 & 24.20 & Oil \\
\hline A3 & 6067.59 & 6582.94 & 515.35 & 511.25 & 0.99 & 0.00 & 0.16 & 72.82 & 0.70 & 0.44 & 0.56 & 22.50 & Oil \\
\hline A4 & 6665.61 & 7427.00 & 761.39 & 752.13 & 0.99 & 0.00 & 0.11 & 3.42 & 1.30 & 1.00 & 1.00 & 11.50 & Water \\
\hline A5 & 7482.22 & 7766.21 & 283.99 & 278.72 & 0.98 & 0.00 & 0.11 & 3.42 & 1.30 & 1.00 & 1.00 & 2.67 & Water \\
\hline A6 & 7892.42 & 7989.08 & 96.66 & 10.50 & 0.11 & 0.14 & 0.26 & 3016.76 & 1.30 & 1.00 & 1.00 & 2.18 & Water \\
\hline A7 & 8272.96 & 8420.95 & 147.99 & 132.50 & 0.89 & 0.07 & 0.38 & 75273.41 & 0.23 & 0.36 & 0.64 & 51.50 & Gas \\
\hline A8 & 8491.94 & 8633.94 & 142.00 & 119.34 & 0.84 & 0.15 & 0.29 & 7587.03 & 1.30 & 1.00 & 1.00 & 1.90 & Water \\
\hline A9 & 8697.04 & 8807.48 & 110.44 & 106.00 & 0.96 & 0.00 & 0.11 & 3.42 & 1.30 & 1.00 & 1.00 & 1.47 & Water \\
\hline A10 & 8886.37 & 8965.25 & 78.88 & 76.88 & 0.97 & 0.00 & 0.11 & 3.42 & 1.30 & 1.00 & 1.00 & 1.12 & Water \\
\hline A11 & 9067.80 & 9178.24 & 110.44 & 105.20 & 0.95 & 0.00 & 0.11 & 3.42 & 1.30 & 1.00 & 1.00 & 1.55 & Water \\
\hline A12 & 9233.46 & 9367.56 & 134.01 & 66.00 & 0.48 & 0.13 & 0.28 & 6164.56 & 1.30 & 0.98 & 0.02 & 1.13 & Water \\
\hline A13 & 9730.55 & 9769.88 & 39.33 & 21.13 & 0.54 & 0.01 & 0.38 & 75873.41 & 0.34 & 0.38 & 0.62 & 52.00 & Oil \\
\hline A14 & 9809.32 & 9864.54 & 55.22 & 32.00 & 0.57 & 0.15 & 0.27 & 4941.59 & 1.30 & 1.00 & 1.00 & 2.31 & Water \\
\hline
\end{tabular}

$N / G$ net to gross, $A v V_{c l}$ average volume of clay, $A v$ Phi $E$ average effective porosity, $A v K$ average permeability, $A v S_{w}$ average water saturation, $A v S_{h}$ average hydrocarbon saturation

$=$ porosity values obtained from a porosity $\log$, $R_{\mathrm{w}}=$ resistivity of formation water. The product of formation water saturation $\left(S_{\mathrm{w}}\right)$ and its porosity $(\phi)$ is the bulk volume water.

Thus; $\quad \mathrm{BVW}=S_{\mathrm{w}} \times \phi$ where BVW = bulk volume water, $S_{\mathrm{w}}=$ water saturation and $\phi=$ porosity.

Constant or very close to constant values of the bulk volume water indicate homogenous zone and at irreducible water saturation (Asquith and Krygowski 2004); so, hydrocarbon 
Table 3 Average petrophysical parameters for the reservoirs in JAP-2 well

\begin{tabular}{|c|c|c|c|c|c|c|c|c|c|c|c|c|c|}
\hline $\begin{array}{l}\text { Reservoir } \\
\text { units }\end{array}$ & Top (ft) & $\begin{array}{l}\text { Base } \\
\text { (ft) }\end{array}$ & $\begin{array}{l}\text { Gross } \\
\text { thickness } \\
(\mathrm{ft})\end{array}$ & $\begin{array}{l}\text { Net } \\
\text { thickness } \\
\text { (ft) }\end{array}$ & $\mathrm{N} / \mathrm{G}$ & $\begin{array}{l}\mathrm{Av} V_{\mathrm{cl}} \\
(\mathrm{v} / \mathrm{v})\end{array}$ & $\begin{array}{l}\text { Av phi } \\
E(\mathrm{v} / \mathrm{v})\end{array}$ & $\begin{array}{l}\mathrm{Av} \\
K(\mathrm{md})\end{array}$ & $\begin{array}{l}\text { Av } \\
\text { MHI }\end{array}$ & $\begin{array}{l}\text { Av } S_{\mathrm{w}} \\
(\mathrm{v} / \mathrm{v})\end{array}$ & $\begin{array}{l}\mathrm{Av} \\
S_{\mathrm{h}}\end{array}$ & $\begin{array}{l}\text { Av } \\
\text { resistivity } \\
(\Omega \mathrm{m})\end{array}$ & $\begin{array}{l}\text { Fluid } \\
\text { type }\end{array}$ \\
\hline A4 & 6565.14 & 7246.10 & 680.97 & 657.50 & 0.96 & 0.14 & 0.28 & 6164.56 & 1.00 & 0.76 & 0.24 & 1.95 & Water \\
\hline A5 & 7545.57 & 7751.08 & 405.51 & 402.50 & 0.99 & 0.14 & 0.25 & 2384.18 & 1.00 & 1.00 & 1.00 & 1.78 & Water \\
\hline A6 & 7888.80 & 7955.67 & 68.87 & 68.87 & 1.00 & 0.01 & 0.29 & 7587.03 & 1.16 & 0.55 & 0.45 & 29.11 & Water/gas \\
\hline A7 & 8248.41 & 8393.79 & 145.38 & 140.50 & 0.97 & 0.08 & 0.31 & 15408.05 & 0.44 & 0.14 & 0.86 & 40.70 & Gas \\
\hline A8 & 8477.95 & 8592.72 & 114.77 & 114.77 & 1.00 & 0.10 & 0.30 & 9298.47 & 0.45 & 0.38 & 0.62 & 10.10 & Oil \\
\hline A9 & 8669.23 & 8768.70 & 99.47 & 99.47 & 1.00 & 0.17 & 0.30 & 9298.47 & 0.49 & 0.45 & 0.55 & 1.80 & Oil \\
\hline A10 & 8856.33 & 8877.22 & 20.89 & 20.00 & 0.96 & 0.13 & 0.31 & 15408.05 & 0.51 & 0.44 & 0.56 & 1.33 & Oil \\
\hline A11 & 9002.55 & 9112.21 & 109.66 & 109.66 & 1.00 & 0.09 & 0.31 & 15408.05 & 0.50 & 0.42 & 0.58 & 1.31 & Oil \\
\hline A12 & 9608.29 & 9670.95 & 62.66 & 56.75 & 0.90 & 0.05 & 0.26 & 3016.76 & 0.90 & 0.33 & 0.67 & 68.00 & Gas \\
\hline A13 & 9688.62 & 9806.72 & 118.01 & 92.56 & 0.78 & 0.05 & 0.26 & 3016.76 & 0.70 & 0.44 & 0.56 & 72.50 & Oil \\
\hline A14 & 9872.61 & 9858.94 & 13.67 & 10.50 & 0.77 & 0.14 & 0.25 & 2384.18 & 1.00 & 1.00 & 1.00 & 1.22 & Water \\
\hline
\end{tabular}

$N / G$ net to gross, $A v V_{c l}$ average volume of clay, $A v P h i E$ average effective porosity, $A v K$ average permeability, $A v S_{w}$ average water saturation, $A v S_{h}$ average hydrocarbon saturation

Table 4 Average petrophysical parameters for the reservoirs in JAP-3 well

\begin{tabular}{|c|c|c|c|c|c|c|c|c|c|c|c|c|c|}
\hline $\begin{array}{l}\text { Reservoir } \\
\text { units }\end{array}$ & Top (ft) & $\begin{array}{l}\text { Base } \\
(\mathrm{ft})\end{array}$ & $\begin{array}{l}\text { Gross } \\
(\mathrm{ft})\end{array}$ & $\begin{array}{l}\text { Net } \\
\text { (ft) }\end{array}$ & N/G & $\begin{array}{l}\mathrm{Av} V_{\mathrm{cl}} \\
(\mathrm{v} / \mathrm{v})\end{array}$ & $\begin{array}{l}\text { Av Phi } \\
E(\mathrm{v} / \mathrm{v})\end{array}$ & $\begin{array}{l}\text { Av } \\
K(\mathrm{md})\end{array}$ & $\begin{array}{l}\text { Av } \\
\text { MHI }\end{array}$ & $\begin{array}{l}\text { Av } S_{\mathrm{w}} \\
(\mathrm{v} / \mathrm{v})\end{array}$ & $\begin{array}{l}\mathrm{Av} \\
S_{\mathrm{h}(\mathrm{v} / \mathrm{v})}\end{array}$ & $\begin{array}{l}\text { Av resistivity } \\
(\Omega \mathrm{m})\end{array}$ & $\begin{array}{l}\text { Fluid } \\
\text { type }\end{array}$ \\
\hline A8 & 8660.03 & 8748.19 & 88.16 & 85.50 & 0.96 & 0.14 & 0.27 & 4941.59 & 0.96 & 0.75 & 0.25 & 2.40 & Water \\
\hline A9 & 8854.91 & 8952.35 & 97.44 & 95.50 & 0.98 & 0.03 & 0.31 & 15408.05 & 0.90 & 0.21 & 0.79 & 45.50 & Gas \\
\hline A10 & 9017.31 & 9068.71 & 51.40 & 50.25 & 0.98 & 0.15 & 0.30 & 9298.41 & 0.91 & 0.92 & 0.08 & 1.34 & Water \\
\hline A11 & 9448.84 & 9509.16 & 60.32 & 57.00 & 0.95 & 0.05 & 0.29 & 7587.03 & 1.00 & 0.23 & 0.77 & 31.20 & Gas \\
\hline A12 & 9541.64 & 9569.48 & 27.84 & 27.84 & 1.00 & 0.06 & 0.27 & 4941.59 & 1.00 & 0.25 & 0.75 & 54.30 & Oil/water \\
\hline A13 & 9597.32 & 9643.72 & 46.40 & 46.40 & 1.00 & 0.03 & 0.28 & 6164.56 & 1.00 & 0.15 & 0.85 & 34.30 & Gas \\
\hline A14 & 9666.92 & 9759.72 & 92.80 & 90.13 & 0.97 & 0.03 & 0.27 & 4941.56 & 1.00 & 0.35 & 0.65 & 90.45 & Oil \\
\hline A15 & 9778.25 & 9866.45 & 88.20 & 78.50 & 0.89 & 0.14 & 0.29 & 7587.03 & 1.00 & 0.91 & 0.09 & 2.59 & Water \\
\hline
\end{tabular}

$N / G$ net to gross, $A v V_{c l}$ average volume of clay, $A v P h i E$ average effective porosity, $A v K$ average permeability, $A v S_{w}$ average water saturation, $A v S_{h}$ average hydrocarbon saturation

Table 5 Average petrophysical parameters for the reservoirs in JAP-4 well

\begin{tabular}{|c|c|c|c|c|c|c|c|c|c|c|c|c|c|}
\hline $\begin{array}{l}\text { Reservoir } \\
\text { units }\end{array}$ & Top (ft) & $\begin{array}{l}\text { Base } \\
(\mathrm{ft})\end{array}$ & $\begin{array}{l}\text { Gross } \\
\text { (ft) }\end{array}$ & $\begin{array}{l}\text { Net } \\
(\mathrm{ft})\end{array}$ & N/G & $\begin{array}{l}\mathrm{Av} V_{\mathrm{cl}} \\
(\mathrm{v} / \mathrm{v})\end{array}$ & $\begin{array}{l}\text { Av Phi } \\
E(\mathrm{v} / \mathrm{v})\end{array}$ & $\begin{array}{l}\mathrm{Av} \\
K(\mathrm{md})\end{array}$ & $\begin{array}{l}\text { Av } \\
\text { MHI }\end{array}$ & $\begin{array}{l}\operatorname{Av} S_{\mathrm{w}} \\
(\mathrm{v} / \mathrm{v})\end{array}$ & $\begin{array}{l}\text { Av } S_{\mathrm{h}} \\
(\mathrm{v} / \mathrm{v})\end{array}$ & $\begin{array}{l}\text { Av } \\
\text { Resistivity } \\
\Omega \mathrm{m}\end{array}$ & $\begin{array}{l}\text { Fluid } \\
\text { type }\end{array}$ \\
\hline A9 & 8882.67 & 8978.29 & 95.61 & 95.61 & 1.00 & 0.01 & 0.28 & 6164.56 & 1.00 & 0.85 & 0.15 & 1.42 & Water \\
\hline A10 & 9010.16 & 9084.54 & 75.38 & 74.00 & 0.99 & 0.13 & 0.27 & 4941.59 & 1.00 & 0.84 & 0.16 & 1.40 & Water \\
\hline A11 & 9158.91 & 9238.28 & 79.37 & 79.37 & 1.00 & 0.01 & 0.28 & 6164.56 & 1.00 & 0.61 & 0.39 & 1.62 & Water/oil \\
\hline A12 & 9291.71 & 9350.15 & 58.44 & 58.50 & 1.00 & 0.02 & 0.24 & 1866.24 & 1.00 & 0.23 & 0.77 & 50.04 & Oil \\
\hline A13 & 9424.52 & 9536.08 & 111.56 & 111.56 & 1.00 & 0.03 & 0.24 & 1866.24 & 1.00 & 0.23 & 0.77 & 56.00 & Oil \\
\hline A14 & 9599.82 & 9695.45 & 95.63 & 93.50 & 0.98 & 0.02 & 0.25 & 2384.18 & 1.00 & 0.28 & 0.72 & 69.04 & Oil \\
\hline A15 & 9722.01 & 9966.37 & 244.36 & 240.50 & 0.98 & 0.01 & 0.29 & 7587.03 & 1.00 & 0.43 & 0.57 & 63.00 & Oil \\
\hline
\end{tabular}

$N / G$ net to gross, $A v V_{c l}$ average volume of clay, $A v P h i E$ average effective porosity, $A v K$ average permeability, $A v S_{w}$ average water saturation, $A v S_{h}$ average hydrocarbon saturation 


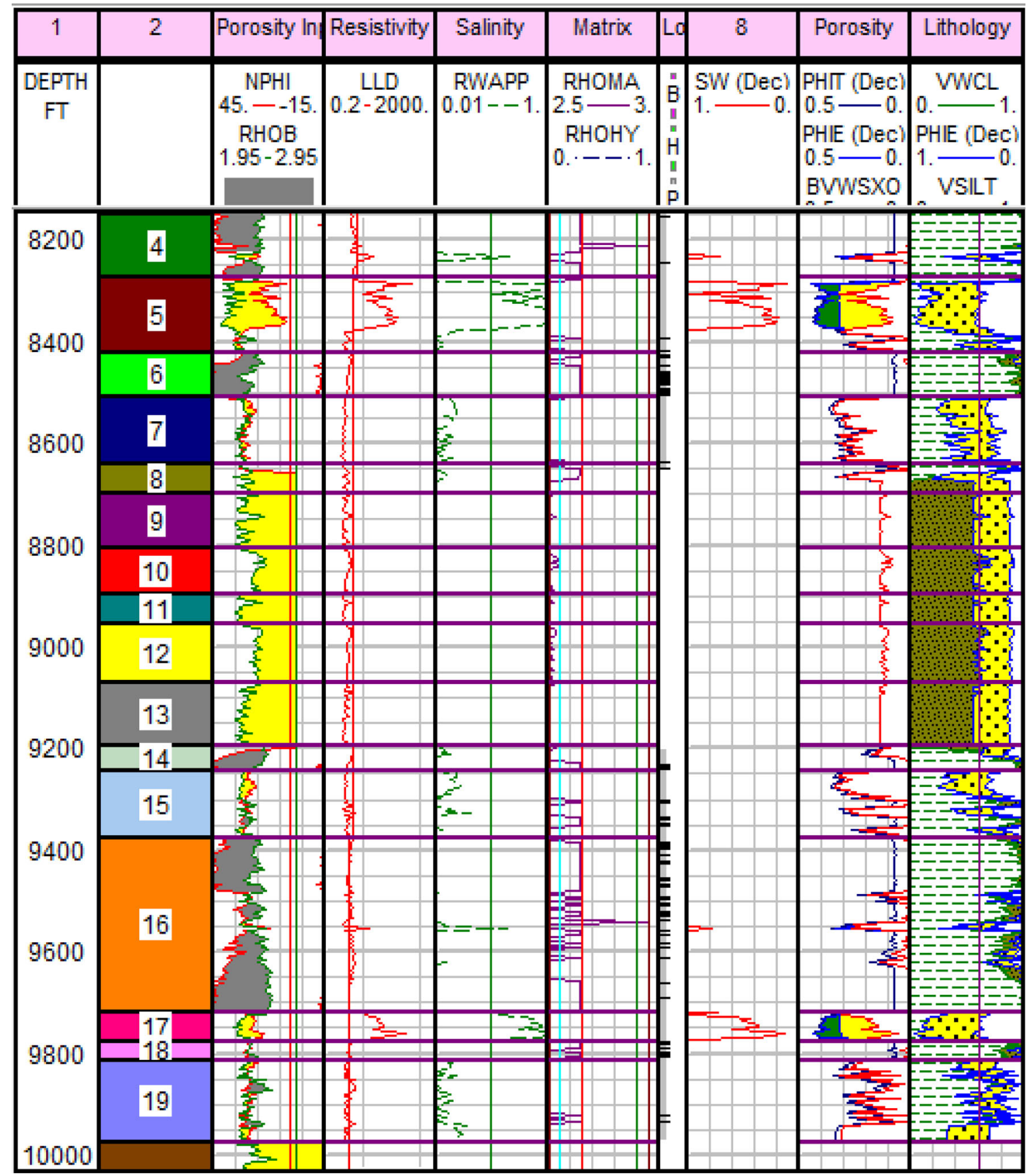

Fig. 6 Estimated porosity, water saturation and fluid types present in JAP-1 well

production from a zone at irreducible water saturation should be water free (Morris and Briggs 1967). Also, the index of oil movability was evaluated as the ratio of water saturation $\left(S_{\mathrm{w}}\right)$ in the uninvaded zone to that of mud filtrate saturation $\left(S_{\mathrm{xo}}\right)$ in the flushed zone. Whenever the movable hydrocarbon index is equal to or greater than 1 , hydrocarbons were not moved during the invasion (Schlumberger 1989).

$\mathrm{IOM}=S_{\mathrm{w} / S_{\mathrm{xo}}}=\left[\frac{R_{\mathrm{xo}} / R_{\mathrm{t}}}{R_{\mathrm{mf}} / R_{\mathrm{w}}}\right]^{1 / 2}$ where $\mathrm{IOM}=$ index of oil movability, $S_{\mathrm{xo}}=$ invaded zone saturation, $R_{\mathrm{mf}}=$ resistivity of mud filtrate, $R_{\text {xo }}=$ resistivity of invaded zone, $S_{\mathrm{w}}=$ Archie-derived water saturation, $R_{\mathrm{w}}=$ resistivity of water and $R_{\mathrm{t}}=$ true resistivity.

The Wyllie and Rose (1950) relations were used to obtain permeability value for the delineated reservoirs.

$K=\left[250 \times \phi^{3} / S_{\text {wirr }}\right]^{2}($ for oil $)$ 


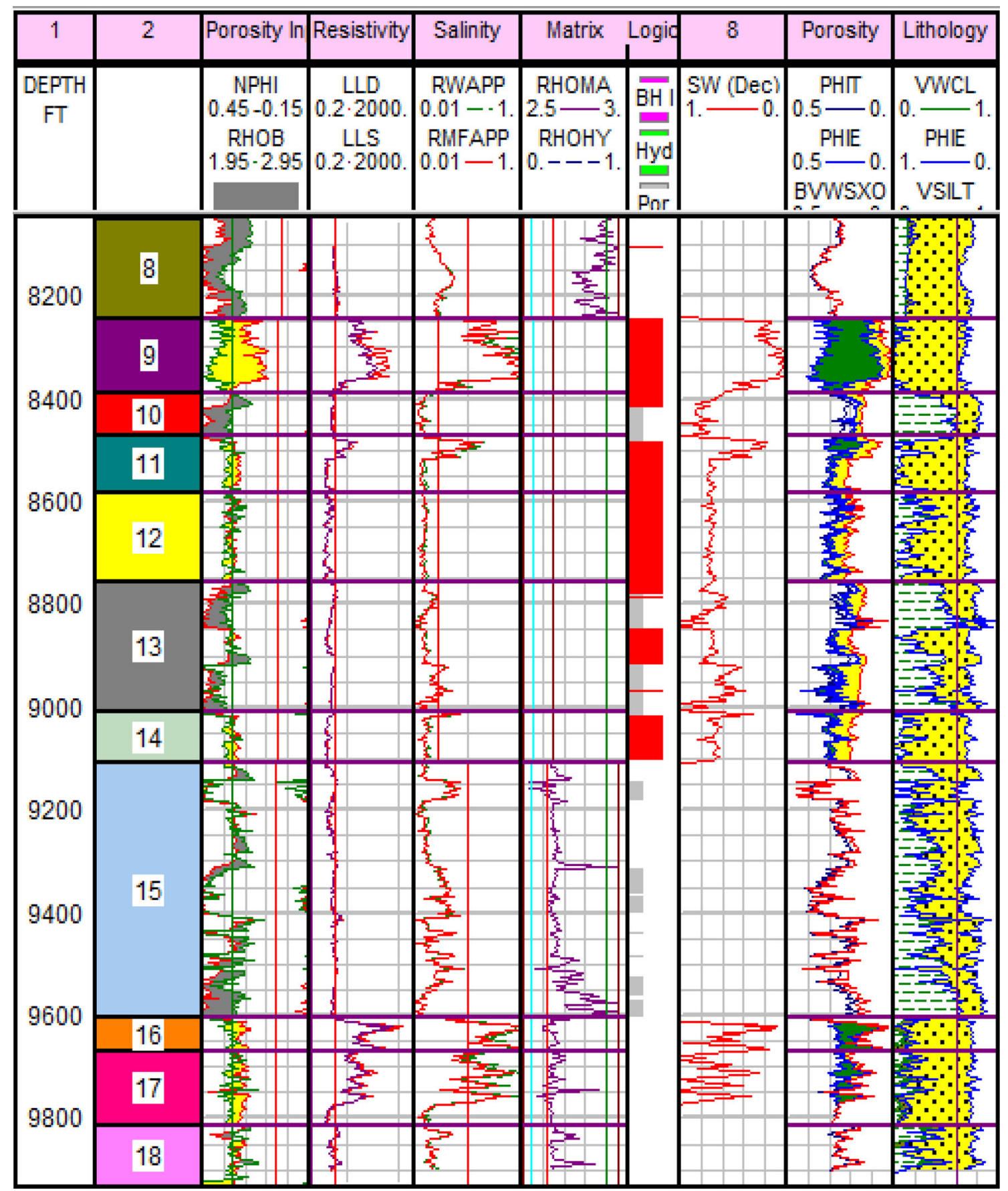

Fig. 7 Estimated porosity, water saturation and fluid types present in JAP-2 well

$K=\left[79 \times \phi^{3} / S_{\text {wirr }}\right]^{2}$ (for dry gas)

where $k=$ permeability in millidarcies, $\phi=$ porosity, $S_{\text {wirr }}=$ irreducible water saturation.

Additionally, the clay/shale form distribution trends in the reservoirs were predicted using the neutron-density crossplot model in order to identify the actual clay form(s) in the sand matrix and how they affect the pore volume estimation.

\section{Results and discussions}

The well correlation panel (north-south, i.e., down-dip) shows that at the shallow and intermediate intervals, there appears to be a thickening of sediment packages toward the south (i.e., as the delta prograded distally) except in reservoir A5, where there is a thinning of sediments downdip (Figs. 3, 4 and 5). However, this could be as a result of delay in the times of deposition or difference in the volume 


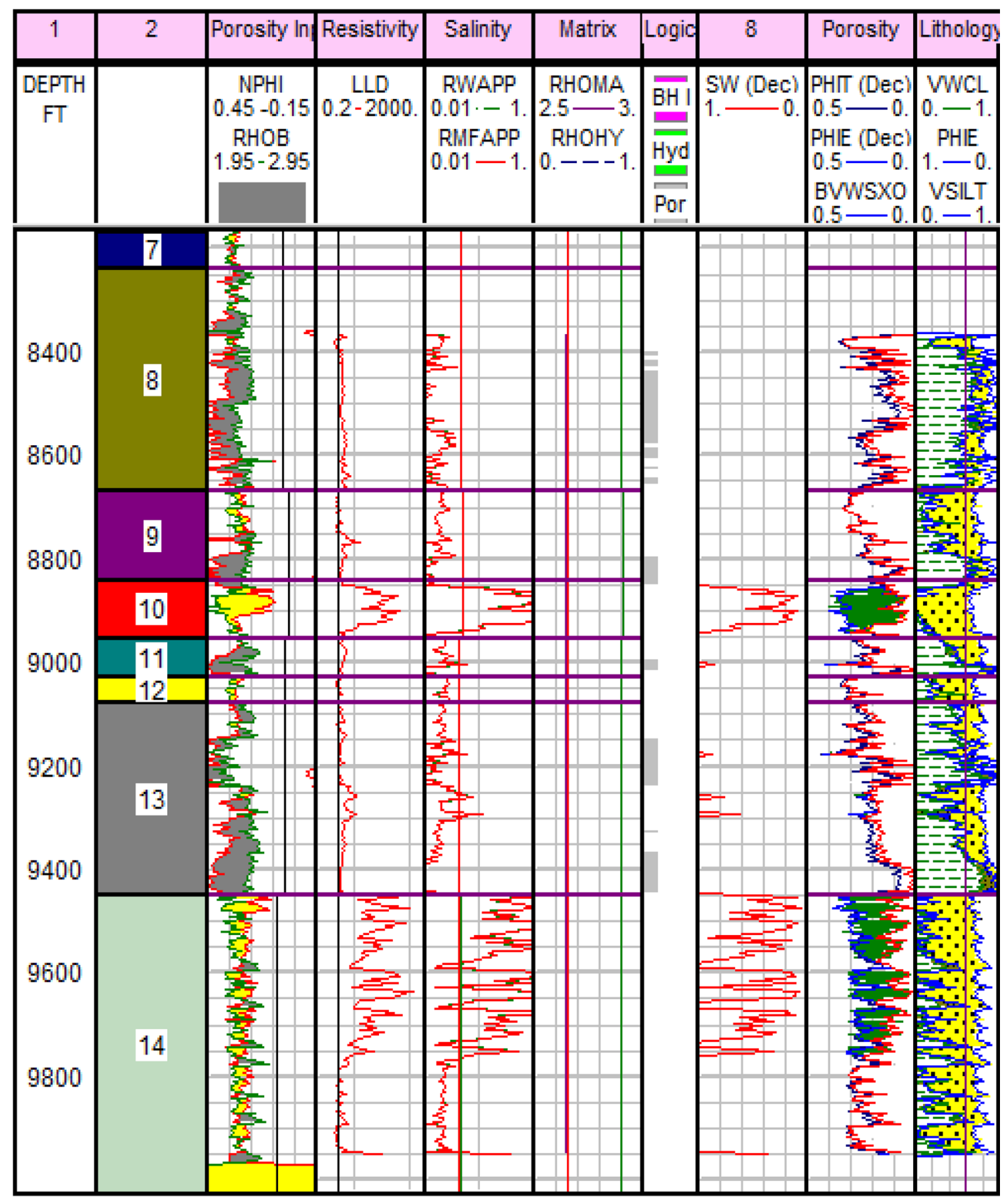

Fig. 8 Estimated porosity, water saturation and fluid types present in JAP-3 well

of sediments deposited per time. At the deeper intervals, there is thickening of sediment package at the central section where reservoirs are also juxtaposed against shale. A total of fifteen (15) reservoirs (A1-A15) were identified (Figs. 3, 4 and 5), and they seem to be laterally continuous. There is a remarkable increase in reservoir thickness as the delta prograded basinward, giving rise to good sand development down-dip at the shallow and intermediate intervals. On the other hand, there is thinning of sediments from south-north (up-dip) and thickening of sand packages at the central part where there is displacement of some correlatable reservoirs at depth. The correlation across dip suggests that horizontal migration of reservoir fluids will be favoured compared to vertical flows. This is owing to the presence of shale baffles which is present almost in all reservoir intervals.

With the use of gamma ray (GR) log motifs alone (Kendall 2003), four major trends which are environmental 


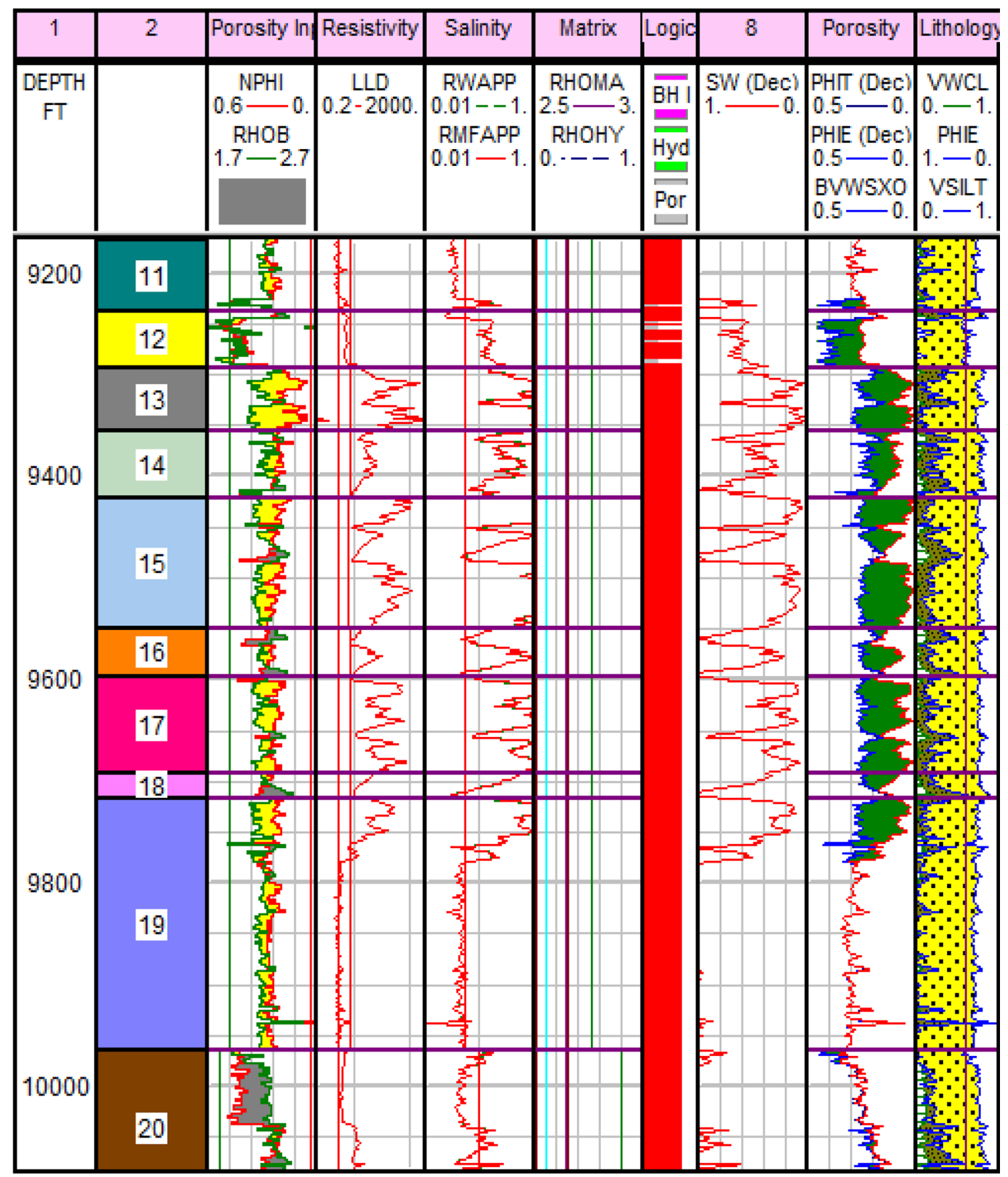

Fig. 9 Estimated porosity, water saturation and fluid types present in JAP-4 well

indicators were identified, namely blocky/cylindrical shape, bell shape, funnel shape and serrated (irregular) shape, which depict distributary channel fill, fluvial channel, shoreface and coastal plain environments, respectively. The blocky-shaped motifs show relatively uniform grain size (aggradational), indicating wave-dominated deltaic distributary channels with clean, well-sorted sands. Also, the bell-shaped motifs are observed as finning upwards of the fluvial channel system with decrease in grain size upwards. The funnel-shaped signature shows coarsening upward units from thinly interbedded sandstone and mud to sandy delta front typical of shoreface. Similarly, the serrated-shaped shows irregular log motifs which depict heterolithic flood plain deposits. From the interpreted log motifs (Table 1; Figs. 3, 4 and 5), it was observed that reservoirs A1-A5, A8, A10 and A12-A14 are wave-dominated distributary channels; A7 and A11 are fluvial channels; A9 and A15 are shoreface sands, while only A6 


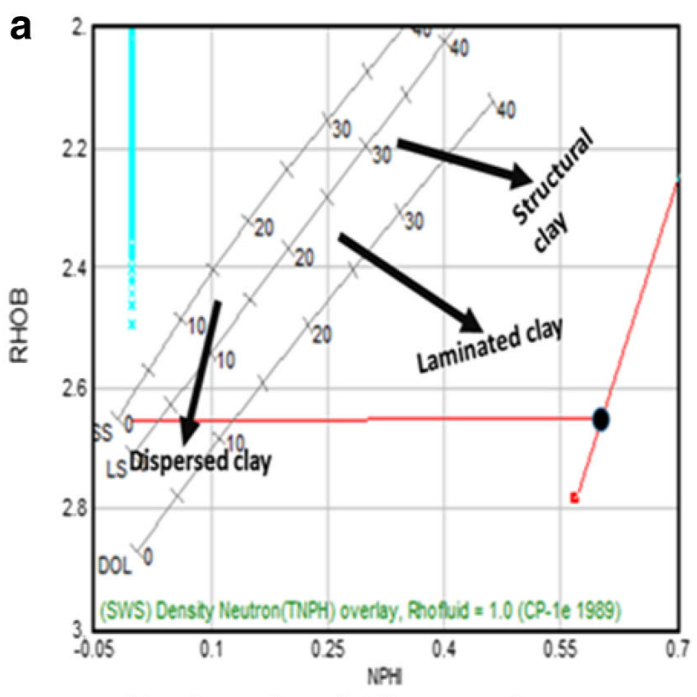

Clay free plot of $\mathrm{A} 2$ reservoir

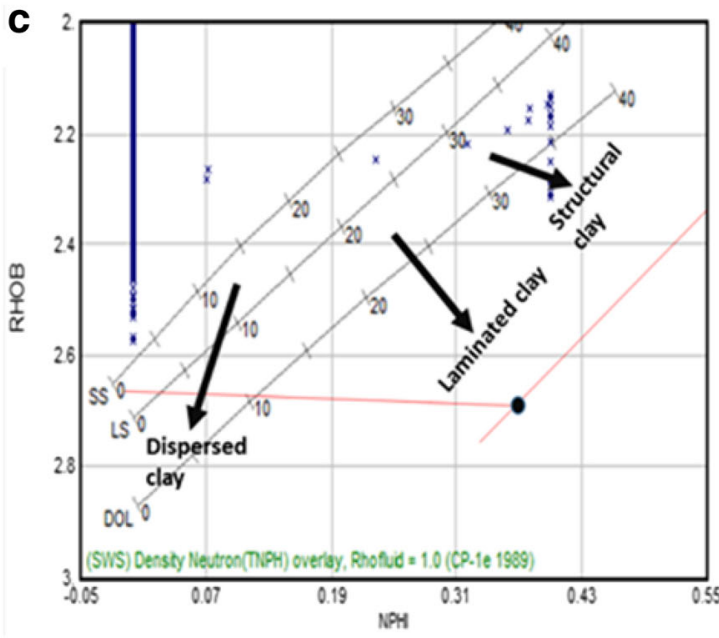

Structural clay plot of A7 reservoir

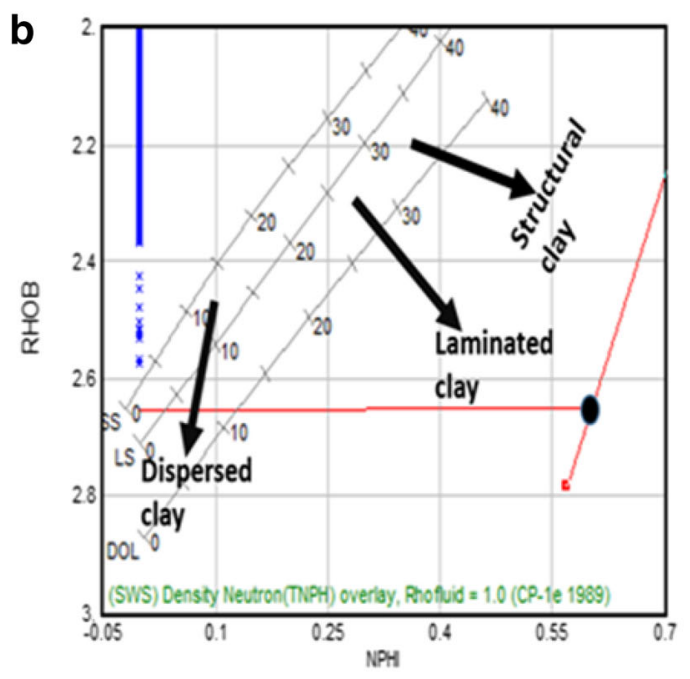

Clay free plot of $A 3$ reservoir

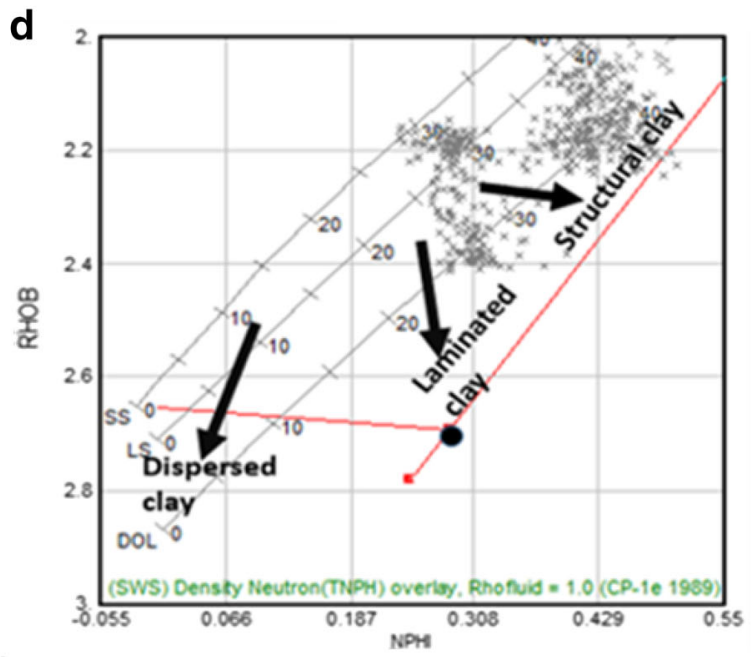

Structural clay plot of A 13 reservoir

Fig. 10 Neutron-density crossplot model showing the clay distributions in the reservoirs a A2, b A3, c A7 and d A13 of JAP- 1 well

is of coastal plain deposit. Their porosity values show that all the reservoirs in the four wells have good-excellent values that range from 0.15 to $0.38 \mathrm{v} / \mathrm{v}(15-38 \%)$ (Tables 2, 3, 4 and 5) except in JAP-1 well where reservoirs A4, A5 and A9-A11 have poor to fair value of 0.11 $\mathrm{v} / \mathrm{v}(11 \%)$ (Table 2). This therefore implies that the general depositional environment of the study field lies within the marginal marine environment that is of relatively high energy.

The results of the petrophysical evaluations show that five of the fourteen delineated reservoirs in JAP-1 well contain hydrocarbons. Reservoirs A1, A2, A3 and A13 contain oil, while reservoir A7 contains gas with an average hydrocarbon saturation range of $0.52-0.0 .71 \mathrm{v} / \mathrm{v}(52-71 \%)$. The netgross for the reservoirs ranges from $54 \%$ in $\mathrm{A} 7$ to $100 \%$ in A2 reservoir (Fig. 6; Table 2). Also, the average volume of clay $\left(V_{\text {clay }}\right)$ values of $0.00-0.14 \mathrm{v} / \mathrm{v}$ is below the damaging limits of $0.15 \mathrm{v} / \mathrm{v}$ (Hilchie 1978). The average porosities for the hydrocarbon bearing sands range from 0.15 to $0.38 \mathrm{v} / \mathrm{v}$ (15-38\%) with permeability range of 42.12-75873.41 md. Hence, the reservoirs have good to excellent porosity and good permeability as well. In JAP-2 well, a total of eight reservoirs (A6-A13) out of ten delineated reservoirs contain hydrocarbon, while the remaining two contain water (Fig. 7; Table 3). The average porosities range from 0.26 to $0.31 \mathrm{v} / \mathrm{v}$ (26-31\%); permeability ranges from 3016.76 to 15408.05 md with hydrocarbon saturation range of between 0.56 and $0.86 \mathrm{v} / \mathrm{v}(56-86 \%)$. The net-gross values of $0.77-1.0$ show good sand development in the reservoirs, and they also have good to excellent porosity and permeability. The good to excellent porosities confirm the below-limiting values of the volume of clay $(0.1-0.14 \mathrm{v} / \mathrm{v})$ in the reservoirs (see Table 3), which indicates relatively low effect on reservoir quality. 


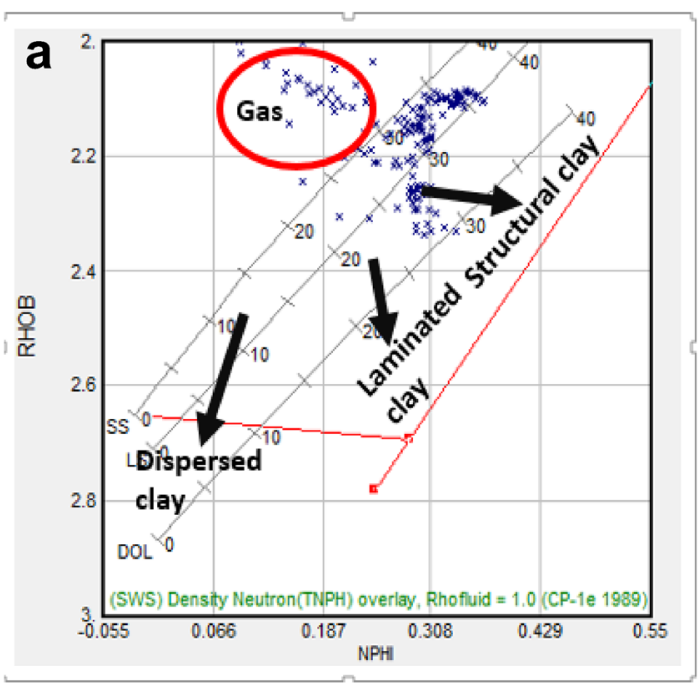

Structural and laminated clays of A6 reservoir

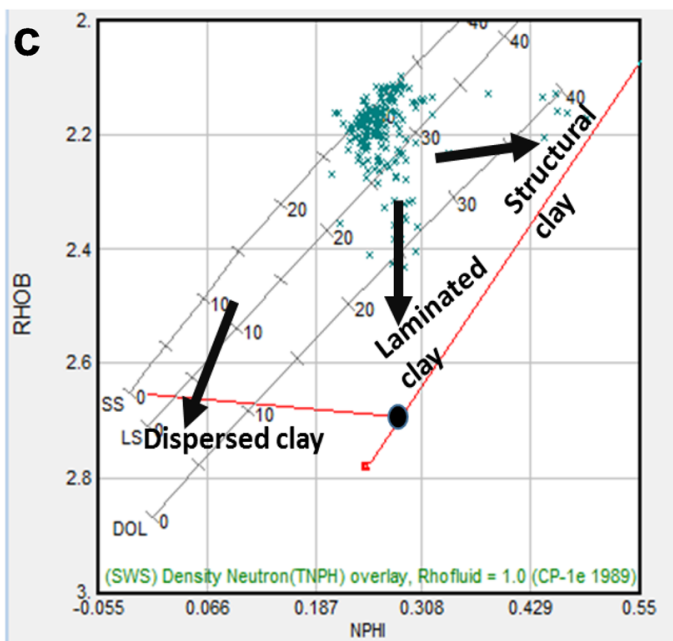

Structural and laminated clays of A12 reservoir

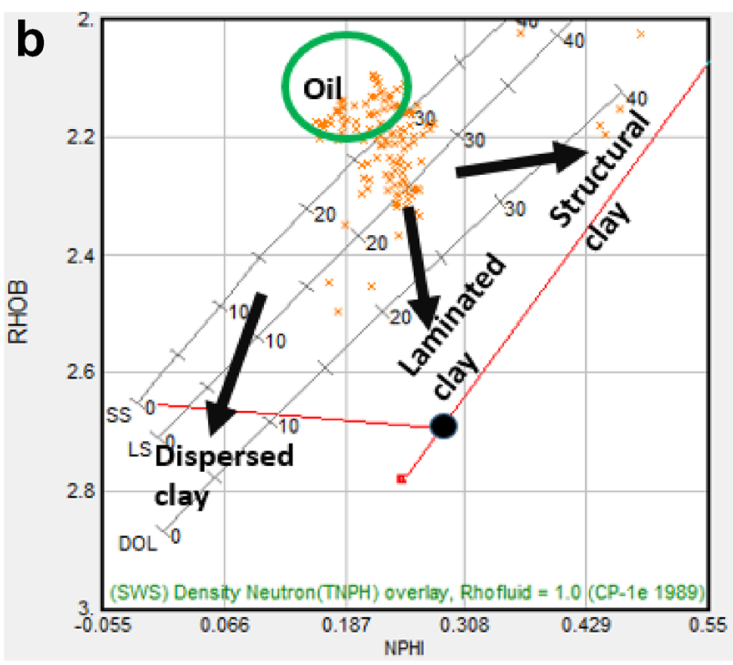

Structural and laminated clays of A8 reservoir

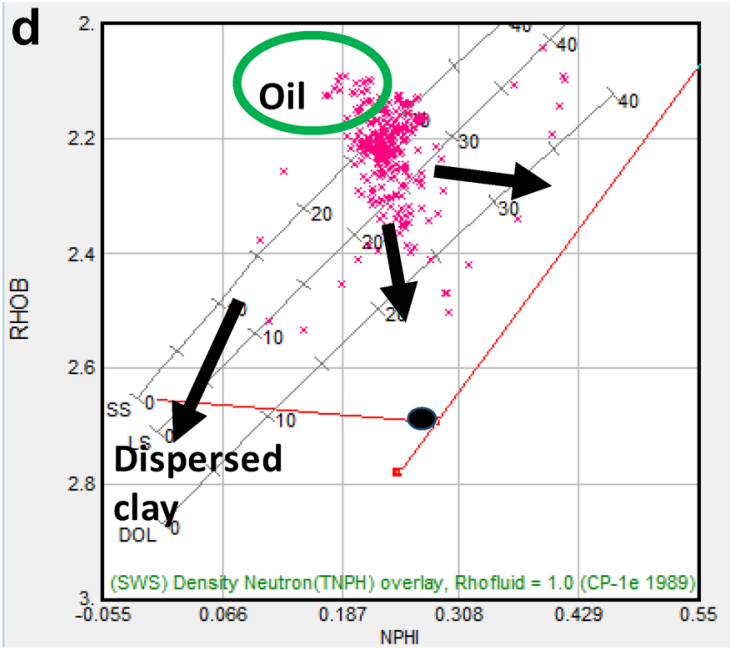

Structural and laminated clays of A 13 reservoir

Fig. 11 Neutron-density crossplot model showing the clay distributions in the reservoirs a A6, b A8, c A12 and d A13 of JAP-2 well

Similarly, the JAP-3 well has five reservoirs (A9, A11, A12, A13 and A14) that contain hydrocarbons. The remaining three reservoirs (A8, A10 and A15) contain water. The volume of shale calculated for the reservoirs range from 0.03 to $0.14 \mathrm{v} / \mathrm{v}$ (3-14\%), which is within the acceptable limits for good reservoir quality (Fig. 8; Table 4). The average porosities range from 0.27 to 0.31 $\mathrm{v} / \mathrm{v}(27-31 \%)$; permeability values range from 4941.59 to $15408.08 \mathrm{md}$ and water saturation of $0.15-0.23 \mathrm{v} / \mathrm{v}$ (15-23\%) for the hydrocarbon bearing sands and $0.75-0.92 \mathrm{v} / \mathrm{v}(75-92 \%)$ for the water bearing sand intervals. The porosity values show good to excellent while the permeability is excellent, translating to better fluid flow through the interstices of the sands. Finally, in JAP-4 well, out of the seven (7) reservoirs delineated, five (5) reservoirs (A11-A15) contain hydrocarbons while the rest contain water (Fig. 9; Table 5). The average porosities for the reservoirs range from 0.24 to $0.29 \mathrm{v} / \mathrm{v}(24-29 \%)$, permeability ranges from 1866.24 to $7587.03 \mathrm{md}$ and water saturations range from 0.23 to 0.50 (23-50\%), which translates to hydrocarbon saturation range of between 0.50 and $0.67 \mathrm{v} / \mathrm{v}(50-67 \%)$.

The clay/shale form distribution pattern from the neutron-density crossplots for the representative reservoirs shows that reservoirs A2 and A3 in JAP-1 well show little or no clay (clay free), which confirms the $0.00 \mathrm{v} / \mathrm{v}$ volume of clay estimated from petrophysical evaluation (Fig. 10; Table 2). This is possible because the wave action that acted on the distributary channel sandstones must have reworked the sediments producing clean and well-sorted sands. The plots also show that reservoirs A7 and A13 contain only structural clays, which indicates that the 


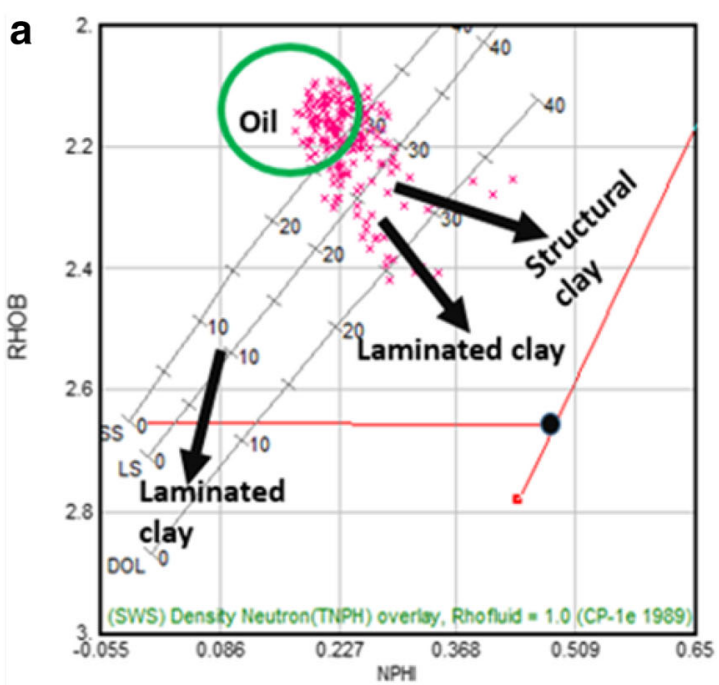

Lamin ated an d stru ctural clay of A12 reservoir

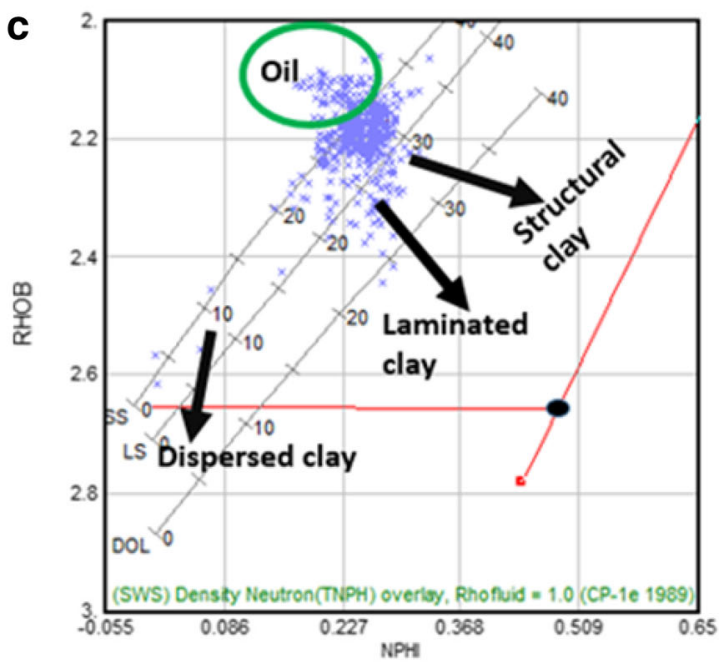

Few laminated and dispersed clay of A.14 reservoir

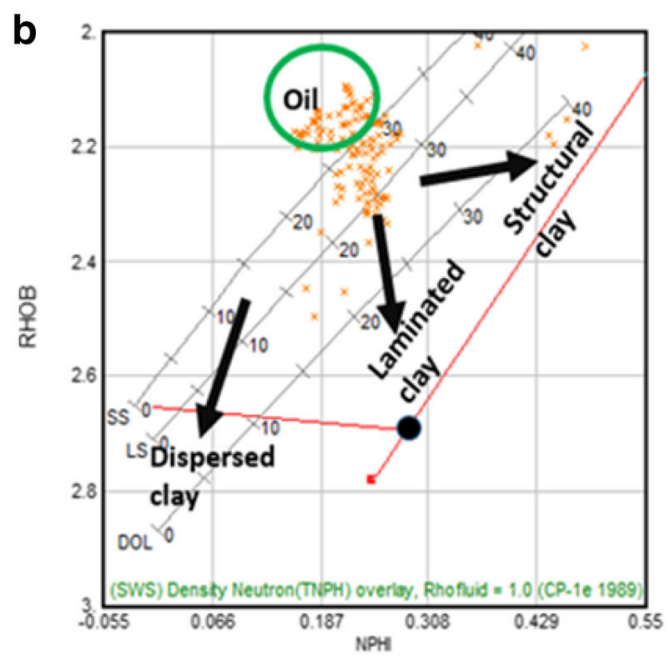

Few laminated and structural clay of A.13 reservoir

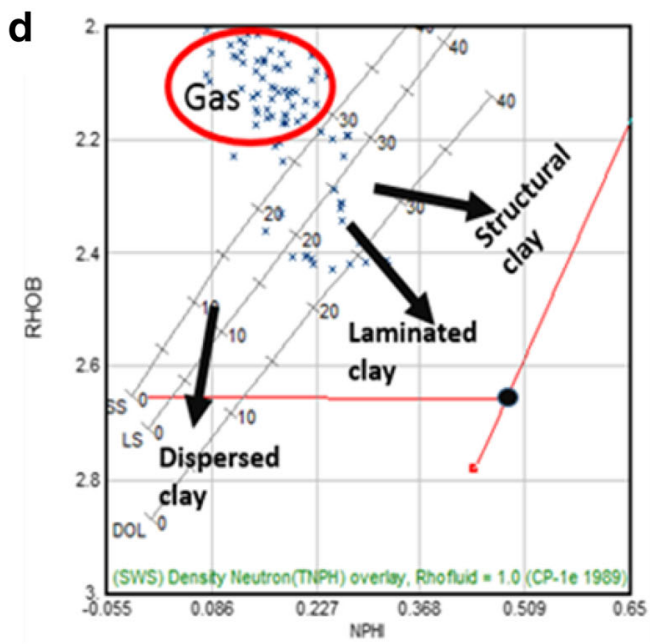

Laminated clay of A.15 reservoir

Fig. 12 Neutron-density model showing the clay distributions in the reservoirs a A12, b A13, c A14 and d A15 of JAP-4 well

effective porosity of the sands are not altered much because structural clays act as framework grains and do not affect the volume of voids of the reservoir. Also, the crossplots of the representative reservoirs (A6, A8, A12 and A13) in JAP-2 well show that all the reservoirs contain laminated and structural clays (Fig. 11). Although the structural clays do not affect reservoir quality, the laminated clays contribute a disproportionate reduction in porosity and occupy the matrix too.

Similarly, the neutron-density crossplots for reservoirs A12-A14 in JAP-4 well show that they contain laminated clays with minor structural and dispersed clays (Fig. 12). Despite the presence of these three clay types, the reservoir qualities of the reservoirs remain relatively high; hence, porosity ranges from 0.24 to $0.29 \mathrm{v} / \mathrm{v}$ and the permeability is in the range of $1866.24-7587.03 \mathrm{md}$ (see Table 5). These results agree with that of Mode et al. (2013). But it is likely that though the horizontal fluid flow may not have been affected, the vertical flow could be impaired due to the presence of numerous laminated clay/shale baffles compartmentalizing the reservoirs.

\section{Conclusions}

This study has shown that the fifteen (15) reservoirs (A1A15) that were delineated are laterally continuous. There is also an increase in reservoir thickness as the delta prograded, giving rise to good sand development down-dip at the shallower and intermediate intervals. Also, the interpreted log motifs indicate that the reservoirs' depositional environments span from coastal plain deposits, fluvial channel through tidal channel to shoreface. All these subenvironments are within the marginal marine that is of

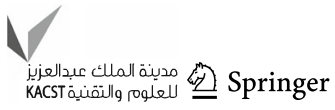


relatively high energy. The reservoir porosities of these sands show good-excellent values that range from 0.15 to $0.38 \mathrm{v} / \mathrm{v}(15-38 \%)$ except in JAP-1 well where reservoirs A4, A5 and A9-A11 have poor to fair value of $0.11 \mathrm{v} / \mathrm{v}$ (11\%). Also, the permeability values are good to excellent (1866.24-75873.41 md), except in few sands of JAP-1 well, where they are relatively low to moderate (3.42-72.82 md). Additionally, the clay/shale form differentiation crossplots show that the reservoirs contain mainly laminated and structural clays with few dispersed clays. Despite the presence of these three clay types, the reservoir qualities of the reservoirs are seldom affected negatively. Inasmuch as the horizontal fluid flow may not have been affected due to good porosity, the vertical flow could be impaired as a result of the presence of numerous laminated clay/shale baffles compartmentalizing the reservoirs. This research has also shown that well logs can be used as an alternative to core data in determining the clay/shale distribution trends in sands and the degree of their negative effects of their reservoir qualities.

Open Access This article is distributed under the terms of the Creative Commons Attribution 4.0 International License (http:// creativecommons.org/licenses/by/4.0/), which permits unrestricted use, distribution, and reproduction in any medium, provided you give appropriate credit to the original author(s) and the source, provide a link to the Creative Commons license, and indicate if changes were made.

\section{References}

Asquith G, Krygowski D (2004) Basin well log analysis. American Association of Petroleum Geologist (AAPG) Methods in Exploration Series, p 16

Avbovbo AA (1978) Tertiary lithostratigraphy of the Niger Delta. Am Assoc Pet Geol Bull 62:295-300

Burke KCB (1972) Longshore drift, submarine canyon, and submarine fans. Am Assoc Pet Geol Bull 56:1975-1983

Corredor F, Shaw JH, Bilotti F (2005) Structural styles in the deepwater fold and thrust belts of the Niger Delta. Am Assoc Pet Geol Bull 89:753-780

Damuth JE (1994) Neogene gravity tectonics and depositional processes on the deep Niger Delta continental margin. Mar Pet Geol 11:320-346
Doust H, Omatsola E (1990) Niger Delta. In: Edwards JD, Santogrossi PA (eds) Divergent/passive margin basins. American Association of Petroleum Geologist (AAPG) Memoir, vol 48, pp 201-238

Evamy BD, Haremboure J, Kamerling P, Knaap WA, Molloy FA, Rowlands PH (1978) Hydrocarbon habitat of Tertiary Niger Delta. Am Assoc Pet Geol Bull 62:277-298

Fairhead JD, Binks RM (1991) Differential opening of the Central and South Atlantic oceans and the opening of the West African rift system. Tectonophysics 187:191-203

Hilchie DW (1978) Applied openhole log interpretation. D.W. Hilchie Inc, Goldon, p 161

Kendall C (2003) Use of well logs for sequence stratigraphic interpretation of the subsurface. USC sequence stratigraphy web, University of South Carolina. http://strata.geol.sc.edu/index.html

Knox GJ, Omatsola EM (1989) Development of the Cenozoic Niger Delta in terms of the 'escalator regression' model and impact on hydrocarbon distribution. In: Mascle J, Marhino M, Wanesson J (eds) The structure of the Guinean continental margin: implications for the connections between the Central and South Atlantic Oceans. Geologische Rundschau, vol 75, pp 57-70

Larionov VV (1969) Borehole radiometry. U.S.S.R. Nedra, Moscow

Lawrence SR, Munday S, Bray R (2002) Regional geology and geophysics of the eastern Gulf of Guinea (Niger Delta to Rio Muni). Lead Edge 21:1112-1117

Mascle J, Marinho M, Wannesson J (1986) The structure of the Guinean continental margin: implications for the connection between the central and the south Atlantic oceans. Int J Earth Sci 75:57-70

Mode AW, Adepehin EJ, Anyiam OA (2013) Petrophysical effects of clay heterogeneity on reservoirs' properties: case study of "Brown Field" Niger Delta, Nigeria. Nigerian Assoc Pet Explor Bull 25(1):61-69

Morris RL, Briggs WP (1967) Using log-derived values of water saturation and porosity. In: SPWLA annual logging symposium, pp 10-26

Okosun EA, Osterloff P (2014) Ostracod, diatom and radiolarian biostratigraphy of the Niger Delta, Nigeria. Earth Sci Res 3(1):72-93

Schlumberger (1989) Log interpretation principles/applications. Schlumberger Educational Services, Houston, pp 13-19

Short KC, Stauble AJ (1965) Outline of geology of Niger Delta. Am Assoc Pet Geol Bull 51:761-779

Whiteman AJ (1982) Nigeria: its petroleum geology, resources and potential. Graham Trotman 1:166

Wyllie MRJ, Rose WD (1950) Some theoretical considerations related to the quantitative evaluations of the physical characteristics of rock from electric log data. J Pet Technol 189:105-110 